DOI: $10.17516 / 1997-1370-0733$

УДК 81.371

\title{
Image of Siberia and Siberians in English: Linguistic Interpretation of Axiological Meanings
}

\author{
Ekaterina S. Muchkina and Marina A. Bitnerb* \\ a Siberian Federal University \\ Krasnoyarsk, Russian Federation \\ ${ }^{b}$ Krasnoyarsk State Pedagogical University \\ named after V.P. Astafiev \\ Krasnoyarsk, Russian Federation
}

Received 12.10.2020, received in revised form 13.02.2021, accepted 18.03.2021

\begin{abstract}
Languages reveal different value systems represented in linguistic signs. Linguistic signs are full of hidden meanings and implications that need paying attention to in the process of translation into another culture. While interpreting intangible cultural heritage one should consider the differences in the value systems. The article deals with the representation of the regional culture of Siberia in the space of the English language. It is stated that values can be studied via interpreting axiological statements with metaphors and comparative constructions, similes and epithets referring to the toponyms and ethnonyms under study. Such contexts demonstrate the results of axiological interpretation of linguistic units and reveal attitudinal meanings and stereotypes. The authors identify a number of characteristics inherent to the stereotypical image of Siberia in English.
\end{abstract}

Keywords: Siberia, Siberian, ethnonym, toponym, xenonym, cultural heritage, axiological meaning.

Research area: linguistics.

Citation: Muchkina, E.S., Bitner, M.A. (2021). Image of Siberia and Siberians in English: linguistic interpretation of axiological meanings. J. Sib. Fed. Univ. Humanit. Soc. Sci., 14(4), 459-465. DOI: $10.17516 / 1997-1370-0733$.

(C) Siberian Federal University. All rights reserved

* Corresponding author E-mail address: emuchkina@sfu-kras.ru ORCID: 0000-0002-7173-0583 (Muchkina) 


\title{
Образ Сибири и сибиряков в английском языке: опыт лингвистической интерпретации \\ аксиологических значений
}

\author{
Е.С. Мучкинаа, М.А. Битнер ${ }^{6}$ \\ ${ }^{a}$ Сибирский федеральный университет \\ Российская Федерачия, Красноярск \\ ${ }^{\sigma}$ Красноярский государственный педагогический университет \\ им. В.П. Астафьева \\ Российская Федерачия, Красноярск
}

\begin{abstract}
Аннотация. В языках обнаруживаются различные системы ценностей, представленные в языковых знаках. Иными словами, лингвистические знаки полны скрытых значений, на которые следует обращать внимание в процессе трансляции в другую культуру. Признание культурной специфики ценностно-смыслового содержания языковых знаков привело к осознанию необходимости интерпретировать культурное наследие с учетом особенностей аксиологических систем различных языков. В статье рассматривается репрезентация региональной культуры Сибири в пространстве английского языка. Утверждается, что ценности можно изучать, интерпретируя аксиологические суждения, содержащие метафоры и сравнительные конструкции, сравнения и эпитеты с исследуемыми топонимами и этнонимами. Такие контексты демонстрируют результаты аксиологической интерпретации языковых единиц, помогают выявить аксиологические значения и содержательные характеристики стереотипного образа Сибири и сибиряков.
\end{abstract}

Ключевые слова: Сибирь, сибиряк, этноним, топоним, ксеноним, нематериальное культурное наследие, аксиологические системы.

Научная специальность: 10.02.00 - языкознание.

\section{Introduction}

Linguistics adheres to the idea that language is a product and reflection of culture, and linguistic units are carriers of cultural meanings developed by intersubjective and subjective processing of human experience. The result of such cognitive processing is objectified in the language which reflects not so much of the world itself or its properties and relationships, but rather its perception by the cognizing subject.

The interconnection of language and culture is studied from different perspectives: language is considered to be a symbol and a guarantee of keeping national culture (Ameen, Magirovskaya, 2020; Maslova, 2007; Ter-Minasova, 2007); language is researched as one of the main aspects determining cultural identity
(Beregovaya, Karlova, 2020; Lebedko, 2014); language is understood as a verbal representation of ethnic stereotypes (Bar-Tal, 1997; Bartminski, 2005; Bartminski, 2009; Fedor, 2014).

In the framework of the contemporary linguistic paradigm, interpretation of linguistic signs is carried out according to coordinates of the cultural space revealing the basic motives for functioning of words, forms and structures (Kazydub, 2019: 149). This approach makes it possible to reconstruct the value system of cultures manifested in the form of interconnected value judgments (Karasik, 2002). Value judgments are judgments about how good or important something is, based on personal opinions rather than facts (OLD). Such judgments do not describe the world; they prescribe certain attitudes to the world. From linguistic 
point of view evaluative statements are descriptive contexts with modifying words which characterize objects, people, phenomena and relations.

The article is aimed at reconstructing the image of Siberia in the space of the English language on the basis of value judgments with the toponym Siberia and the ethnonym Siberian. It is not by chance that the study focuses on these lexical units as linguistic signs of different levels have varying degrees of cultural sensitivity (Kozlova, 2014).

The representation of the cultural heritage of a linguistic community in the space of another language occurs through culturally and ethnically marked linguistic units, i.e. toponyms (place names) ethnonyms that are relevant to constructing ethnic group identity (Sierra, 2019: 3), and xenonyms - words that describe external culture (Kabakchi, 2020). These units identify the artifacts and values of another culture and also have additional meanings that arise in the evolution of a linguistic sign. Collective linguistic creativity is expressed in metaphorical meanings, metonymy and evaluative statements. It is the background knowledge hidden in the semantics of such signs that becomes the key to understanding the image of a different culture, which has developed in the minds of native speakers.

The hypothesis of the research is based on the idea that culturally-marked vocabulary can actualize evaluative meanings and content characteristics of such a mental construct as an ethnic stereotype in discourse. Such stereotypes tend to be actualized by the units under study when used as descriptions or comparisons, metaphors and metonymies (Muchkina, Bitner, 2015) and/or in specific syntactic patterns, i.e. X is X (Kobozeva, 2007). The authors explore the image of Siberia in English-speaking cultures by analyzing the semantics of the words Siberia and Siberian used in non-specific redefined meanings in axiological contexts.

The relevance of our research is dictated by the need to integrate national culture into the global humanitarian space, popularize the achievements of Russian culture, its historical heritage and specific values. However, the existing prejudice and stereotypes can interfere with the process and prevent Siberia from becoming an attractive investment target, scientific center, historic and cultural destination (Stepchenkova, Morrison, 2006). Revealing stereotypes about the area and its residents can provide a basis for developing a strategy of promoting the region with a rich history and unique tradition.

\section{Methods and Data Collection}

The reconstruction of the stereotypical image and its value-semantic interpretation is carried out through the analysis of axiological statements with the lexemes Siberia and Siberian. Formal markers of evaluative contexts that reveal background knowledge about an object or a phenomenon are word approximators (so Siberian, very Siberian, too Siberian, how Siberian, in a Siberian manner/way), the negation operator in pre-position of an ethnonym or toponym (not Siberian, not Siberia), the use of articles (a Siberia, the Siberia) comparisons (like Siberia). Things and characteristics recognized as very Siberian or so Siberian are inherent to the image of the region. However, the properties qualified as too Siberian, non-Siberian have been revealed to be alien to the concept.

Structural context also matters in revealing specific axiological implications of the word meaning. The evaluative nature of modifiers is fully manifested when the ethnonym functions as a modifier of the whole proposition, as a predicative or an attribute. Thus, the analysis of the semantics also included the analysis of the contextual distribution of the lexemes under study and their syntactic function in the sentence. The interpretation of the meaning started from the dictionary definition, to syntactical and lexical distribution and, finally, the actualizing context of the lexeme.

The data for the study were collected from the most reputable corpora of the English language: Corpus of Contemporary American (COCA) and British National Corpus (BNC). Several contexts were also found in travel diaries, memoirs and newspaper articles.

The logic of the research demanded that units in which the ethnonym Siberian is part of the proper name should be excluded from 
the sample. These names usually include plant or animal species (Siberian husky, tiger, elm, crane, ferret, lemming, iris, ginseng, bugloss, reindeer, etc.) and place names (South-central, Southeastern, Northwest, Arctic, region, etc.).

\section{Semantic Clusters of Stereotypical Image}

Cultural meanings are experienced by a linguistic person in three formats: deontic, epistemic and axiological ones. Deontic meanings are revealed in the form prescriptions, epistemic meanings occur as knowledge, while axiological meanings are actualized as images (Kazydub, 2009: 84). As stereotypical images include pre-existing knowledge, beliefs, presuppositions and ideologies, the scope of their meaning is broader than deontic and epistemic ones. Thus, images include both knowledge and prescriptions but are not limited to them. Verbalized in discourse, images determine communicative behaviour and contribute to the creation of value systems. Studying the image of Siberia in English the authors focused on the contextualized use of culturally-meaningful linguistic units (xenonyms, ethnonyms, toponyms) which tend to evolve till they cease to perform the function of object or place nomination. The derived meaning of the word, however, is pre-determined by its original meaning. Thus, semantic analysis starts from dictionary definitions.

The toponym Siberia is defined by Oxford Learner's Dictionary as 'a vast region of Russia that extends from the Ural Mountains to the Pacific Ocean and from the Arctic coast to the northern borders of Kazakhstan, Mongolia, and China'. The definition further develops the stereotypical image of Siberia listing common facts about Siberian climate (the severity of its winters), history (a place of exile) and natural resources (a major source of minerals and hydroelectric power). These facts give grounds for the secondary meaning presented in the dictionary - 'an extremely cold, barren, or inhospitable place'. Even at the stage of definition analyses it is noted that the name tends to expand the scope of its meaning in the following directions: SIBERIA - COLD AND REMOTE PLACE, SIBERIA - EXILE, SIBE-
RIA - RICH RESOURCES. The dictionaries analysis allows highlighting the components of the word semantics: 'region', 'large', 'vast', 'barren', 'cold', 'remote', 'severe/inhospitable', 'isolated', 'cold'. These semes are further disclosed in discourse and form semantic clusters referring to the following themes: geography, nature and climate, history and politics, cultural heritage.

\section{SIBERIA - COLD AND REMOTE PLACE}

In terms of frequency contexts containing the ethnonym Siberian and designating the place of origin (residence) prevail: Siberian fur, oil, gas, pipeline, peoples, town, village, settlements, city, railway. Geographic remoteness and natural landscape of Siberia are described by the phrases frigid wastelands, wilderness, remote, etc. Natural-geographical component of the meaning is traced in the phrases Siberian permafrost, winter, snow, forest, tundra, taiga, steppes, river, land, coast. They highlight the dominant feature of Siberia's image 'cold and remote'. This meaning is actualized in the context describing Siberian weather and climate ('severe environment', 'winds', 'snow', 'Siberian-like winters'). The seme 'remoteness' accounts for the further metaphorical transfer: 'Siberia $=$ a distant, hard-to-reach place' like in (1), (2), (3).

(1) The guy inside spotted Sonny Black at the wedding. SONNY: What kind of a f**king table is this? We're in $f^{* *}$ king Siberia with this table. (COCA)

(2) Tell him to go to Siberia or somewhere where wolves have never encountered human. (COCA)

(3) He bigger chance we have of somebody giving us a one-way ticket to a Siberian hell hole! (BNC)

The idea of remoteness is further developed as the idea of wildness, primitiveness, being uncivilized (4), (5).

(4)' ... is happy to have a family and a handful of friends and live in a Siberian city where I don't think even $1 \%$ of the population knows what Twitter is.' (BNC)

(5) Siberia is a place, metaphoric and literal: It's an inescapable, brutal state of mind. (COCA) 


\section{SIBERIA - EXILE}

The historical and political aspect of the interpretation of the image is expressed in the following units: 'Soviet Siberia, Stalin Siberia, Gorbachev Siberia, Yeltsin Siberia'. The ethnonym can often be found in the combinations with the words exile, Siberian prison, labor camp, GULAG, etc.

Siberia has been a place of exile for centuries. In the context (6) the place of exile is described as 'little Siberia'.

(6) Brandfort, a tin shack in a tiny township 250 miles from Soweto. So Winnie turned this little Siberia into a place of pilgrimage. (COCA)

The historically-determined image of Siberia as a place where one must survive, struggling with harsh conditions, overcoming isolation is part of the collective history of Siberia and inspires an independent concept of 'Surviving Siberia'.

The structural context with the lexeme $\mathrm{Si}$ beria as a direct object indicates that the word is used metaphorically. Siberia ceases to denote 'a place' (cf. surviving in the desert, surviving in Siberia) but carries the meaning of 'a disaster' (cf. surviving an earthquake, surviving Siberia). (7) Ever since the 17th century, when the frigid wastelands of the empire became a dumping ground for convicts and dissidents, 'surviving Siberia' has been part of Russia's collective culture. The Decembrists symbolize the victory of the human spirit over oppression. They were brilliant men, willing to give up everything for an idea. (COCA)

The Siberian survival scenario includes the components listed in the example below.

(8) Just think, he says: she survived Siberia. Siberia! Survived all those things nearly all the others died of. four weeks in a boxcar, drinking water out of puddles, sleeping on top of corpses, raped thirteen times, the cold, the work and not enough to eat, two bouts of typhus, she'd had to bite into a rotten herring for the salt to save her life, and then the trip back to Germany under the name of a dead person, smuggled among the wounded on a medical transport... (COCA)

\section{SIBERIA - RICH RESOURCES}

The history of Siberia, the reputation of a notorious exile is one of the dominant features building the image of the region. However, another semantic cluster in the structure of the image is pre-determined by the fact that Siberia has been treasure of the country, contributing to its economy (9).

(9) It was a Siberia of the Spanish empire. (COCA)

Siberia is associated with land full of various deposits, mineral resources, oil and gas ('the great natural gas reserves in Siberia', 'dark rich soil', 'mineral and energy resources in Siberia').

\section{SIBERIANS}

The Siberian identity is verbalized by the substantivized adjective Siberian. Siberian identity (like any other) is a cultural or biographical phenomenon. It is based not only on comprehending the territory borders, but also on the way of 'interaction' with the region, feeling the connection with the history of the individual's residence, its intangible cultural heritage.

The uniqueness of Siberian people living (or surviving) under difficult living conditions, weather conditions, has created another semantic field - 'Siberian character'. The concept of Siberian character is presented in the contexts: (10) Siberians have always been brave, freedom-loving and enterprising people. (COCA)

(11) Russian Siberians have been hardened by the harsh climate and difficult living and working conditions. (BNC)

The nomination Siberians is rather neutral as compared with the xenonym «Siberian muzhik». This linguistic unit actualizes the stereotypical image of a male inhabitant of Siberia.

(12) Before setting out for Fyodorovich's I had worried about encounting an eccentric, taciturn recluse. Instead, sitting in front of me was a quintessential «Siberian muzhik», or peasant, a gregarious figure who - in his striking, bearded appearance and unsullied way of life-seemed like a character from the pages of Tolstoy. (F. Montaigne)

(13) I like to imagine myself as a bonnie Highlander or sturdy Siberian muzhik surviving the rigours of winter by pluck and wit alone. (D. Kennedy) 
The stereotype of 'Siberian muzhik' seems to include the components of Siberia's image: the ideas of the bearded appearance, living a simple life and surviving Siberian cold.

\section{Conclusion}

In the study of the verbalized representation of Siberia and its inhabitants in the English language, the authors identified the main parametric characteristics of the meaning expressed by these lexemes. The structure of Siberia's stereotypic image includes the following semantic clusters centred around Siberia's geography, its resources, its history and its people: SIBERIA - COLD AND REMOTE PLACE, SIBERIA - EXILE, SIBERIA RICH RESOURCES. The analysis of the contexts proved that the geographical component of the meaning has the greatest potential for a metaphorical shift. Siberia is associated with remoteness, isolation and a severe climate. The historical and political component of the image is based on the fact that Siberia used to be an exile. This meaning is presented in the contexts about 'surviving Siberia' (Siberia used as a direct object) where the word Siberia functions not as a place name but as a common noun denoting a disaster. The analyzed contexts actualize the values of Siberia's tangible and intangible cultural heritage. The latter includes the recognition of Siberian identity and the value of Siberian character.

In conclusion, the study of linguistic semantics raises the awareness of stereotypical images existing in another culture. The interpretation of culturally-marked linguistic signs representing our culture in other languages can be adequately interpreted provided one takes into consideration axiological meanings conveyed by the word.

\section{References}

Ameen, R.M., Magirovskaya, O.V. (2020). Ethnic Language Use as a Symbol of Keeping the Nation's Culture and Traditions (the Case of the Displaced Peoples' Languages in the Kurdistan Region). In Journal of Siberian Federal University. Humanities \& Social Sciences, 13(3), 286-295.

Bar-Tal, D. (1997). Formation and change of ethnic and national stereotypes: An integrative model. In International Journal of Intercultural Relations, 21(4), 491-523.

Bartminski, J. (2009). Bazovy'e stereotipy' i ix profilirovanie [Basic stereotypes and their profiling]. In Stereotipy'v yazy'ke, kommunikacii i kul ture [Stereotypes in Language, Communication and Culture], 11-21.

Bartminski, J. (2005). Yazy'kovoj obraz mira: ocherki po e'tnolingvistike [Linguistic Image of the World: Essays on Ethnolinguistics]. Moscow, Indrik, 528 p.

Beregovaya, N.Y., Karlova, O.A. (2020). Ideological Phantoms of Civilisation and Culture: Identity and Tolerance. In Journal of Siberian Federal University. Humanities \& Social Sciences, 13(7), 1090-1098. DOI: 10.17516/1997-1370-0413

Fedor, C.G. (2014). Stereotypes and Prejudice in the Perception of the "Other". In Procedia-Social and Behavioral Sciences, 149, 321-326.

Lebedko, M.G. (2014). Interaction of ethnic stereotypes and shared identity in intercultural communication? In Procedia-Social and Behavioral Sciences, 154, 179-183.

Kabakchi, V.V. (2020). Vvedenie v interlingvokul turologiyu [Introducing Interlingioculturology]. Moscow, Yurajt, $250 \mathrm{p}$

Karasik, V.I. (2002). Yazy`kovoj krug: lichnost', koncepty', diskurs [Language Circle Person, Concepts, Discourse]. Volgograd, Peremena, 477 p.

Kazydub, N.N. (2019). Yazy`k i kul 'tura: aksiologicheskie skrepy` [Language and Culture: Axiological Links]. In Gercenovskie chteniya. Inostranny'e yazy'ki [Herzen's Readings. Foreign Languages], 149-151.

Kazydub, N.N. (2009). Aksiologicheskie sistemy` v yazy'ke i rechi [Axiological Systems in Language and Speech]. In Vestnik Irkutskogo gosudarstvennogo lingvisticheskogo universiteta [Bulletin of Irkutsk State Linguistic University], 82-86.

Kobozeva, I.M. (2007). Lingvisticheskaya semantika [Language Semantics]. Moscow, KomKniga, $352 \mathrm{p}$. 
Kozlova, L.A. (2014). O trex sposobax manifestacii kul turno-specificheskogo v leksikone yazy'ka [Three ways of manifesting culture specific meanings in the language lexicon]. In Filologiya i chelovek [Philology and Human], 1, 7-16.

Maslova, V.A. (2007). Homo Lingualis v kul'ture [Homo Lingualis in Culture]. Moscow, Gnozis, 320 p.

Muchkina, E.S., Bitner, M.A. (2015). Realizaciya aksiologicheskogo potenciala e'tnonimov v tekste [Realisation of axiological potential of ethnonyms in the text]. In Vestnik Krasnoyarskogo gosudarstvennogo pedagogicheskogo universiteta im. V.P. Astaf'eva [Bulletin of the Krasnoyarsk State Pedagogical University named after V.P. Astafyev], 3, 173-176.

Oxford Learner's Dictionaries (OLD). Available at: https://www.oxfordlearnersdictionaries.com/definition/english/value-judgement?q=value+judgements (accessed 15 September 2020).

Sierra, S. (2019). Linguistic and ethnic media stereotypes in everyday talk: Humor and identity construction among friends. In Journal of Pragmatics, 152, 186-199.

Stepchenkova, S., Morrison, A.M. (2006). The destination image of Russia: From the online induced perspective. In Tourism management, 27(5), 943-956.

Ter-Minasova, S.G. (2007). Vojna i mir yazy'kov i kul 'tur [War and Peace of Languages and Cultures]. Moscow, AST, 286 p.

\section{List of Sources}

British National Corpus (BNC). Available at: https://www.english-corpora.org/bnc/ (accessed 15 September 2020).

Corpus of Contemporary American English (COCA). Available at: https://www.english-corpora.org/ coca/ (accessed 15 September 2020).

Kennedy, D. (2008). An Ecology of Enchantment: A year in the Life of a Garden. Vancouver: Greystone Books, $336 \mathrm{p}$.

Montaigne, F. (2013). Reeling in Russia: an American Angler in Russia. New York: St. Martin's Press, $292 \mathrm{p}$. 